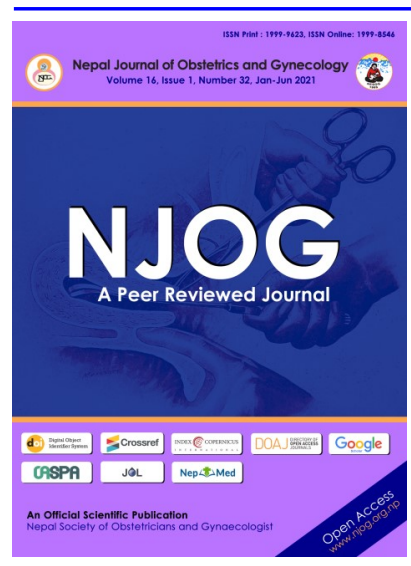

CORRESPONDENCE

Dr Murari Thakur

Provincial Hospital, Janakpur, Nepal

Email: murarithakur45@ gmail.com;

Phone: +977-9866047639

Received: August 12, 2020 Accepted: May 15, 2021

\section{Citation:}

Thakur M. Study of Caesar ean Section using Robson's Classification at Provincial Public Hospital. Nep J Obstet Gynecol. 2021;16 (32):34-37. DOI: https:// doi.org/10.3126/ njog.v16i1.37514

\title{
Study of Caesarean Section using Robson's Classification at Provincial Public Hospital
}

Murari Thakur

Department of obstetrics and Gynecology, Provincial Hospital, Janakpur

\section{ABSTRACT}

Aims: To categorize all pregnant women admitted for delivery at Provincial Public Hospital Janakpurdham according to Robson's ten group classification and to assess the caesarean section rate and identify the indications contributing to the same.

Methods: This is a prospective study conducted at Provincial Public Hospital Janakpurdham for 3 months from $15^{\text {th }}$ April to $15^{\text {th }}$ July 2020 .Total of 1536 participants admitted for delivery including 257 undergoing caesarean section were included in the study and were classified according to the Robson's classification. For each group, demographic and obstetric profile, relative size and its contribution to the overall caesarean rate was calculated.

Results: The overall caesarean section rate was $16.7 \%$ (257 among 1536 total deliveries). Robson's Group 5(Previous caesarean section, singleton cephalic, $\geq 37$ weeks) was the major contributor $(46 \%)$ to the overall caesarean section rate followed by Group $2 \mathrm{~b}$ (nullipara, singleton cephalic, $\geq 37$ weeks, caesarean section before labor) (15.6\%).

Conclusion: Induction of labor for Group 2a and $4 \mathrm{a}$ should be done and trial for vaginal delivery in previous Cesarean section for Group 5 should be promoted to reduce the caesarean section rate. Study result is limited by lack of labor induction facility at the study site.

Keywords: Cesarean section; Robson's classifications

\section{INTRODUCTION}

Cesarean Section (CS) delivery is defined as the birth of a viable fetus through incision in the abdominal wall (laparotomy) and the uterine wall (hysterotomy). ${ }^{1} \mathrm{CS}$ is one of the most commonly performed surgeries in obstetric practice. ${ }^{2}$ A CS can be a lifesaving intervention when medically indicated, but it can also lead to shortterm and long-term health effects for women and newborn. ${ }^{3}$ Therefore it's an international public health concern. ${ }^{4}$ However, WHO have stated that CS rate over $10-15 \%$ at population level cannot be justified. ${ }^{5}$

Robson's classification or Ten group classification system (TGCS) was created to prospectively identify welldefined, clinically relevant groups of women admitted for delivery and to investigate differences in $\mathrm{CS}$ rates within these relatively homogeneous groups of women (Table 1). ${ }^{6}$ It helps to create and implement effective strategies specifically targeted to optimize the CS rates.

\section{METHODS}

This was a prospective study at Provincial Hospital Janakpurdham for 3 months from $15^{\text {th }}$ April 2020 to 15th July 2020. After approval from Ethical review board of Nepal health research Council (NHRC) all pregnant women at or more than 22 weeks gestation admitted for delivery at this hospital were included in the study. Data were collected according to the Robson's classification (Table-1). ${ }^{6}$ Group size, Overall CS rate, Group CS rate, absolute group contribution and relative group contribution to overall CS rate were calculated. Also demographic profile (age and address) and obstetric profile (parity and period of gestation) of women undergoing CS were entered and analyzed in MS Excel.

Table-1: Robson's Classification of cesarean section by Group number

1: Nulliparous women with a single cephalic pregnancy, $\geq 37$ weeks gestation in spontaneous labour

2: Nulliparous women with a single cephalic pregnancy, $\geq 37$ weeks gestation who had labour in- 
duced (2a) or were delivered by CS before labour (2b)

3: Multiparous women without a previous CS, with a single cephalic pregnancy, $\geq 37$ weeks gestation in spontaneous labour

4: Multiparous women without a previous CS, with a single cephalic pregnancy, $\geq 37$ weeks gestation who had labour induced (4a) or were delivered by CS before labour (4b)

5: All multiparous women with at least one previous CS (5a) or more than one previous CS (5b), with a single cephalic pregnancy, $\geq 37$ weeks gestation

6: All nulliparous women with a single breech pregnancy

7: All multiparous women with a single breech pregnancy including women with previous $\mathrm{CS}(\mathrm{s})$

8: All women with multiple pregnancies including women with previous $\mathrm{CS}(\mathrm{s})$

9: All women with a single pregnancy with a transverse or oblique lie, including women with previous $\mathrm{CS}(\mathrm{s})$

10: All women with a single cephalic pregnancy $<$ 37 weeks gestation, including women with previous CS(s)

\section{RESULTS}

Out of total hospital deliveries (1536) in 3 months, majority belonged to Group 3(51\%) while no cases were admitted for labor induction in Group 2a and 4a [Figure-1].

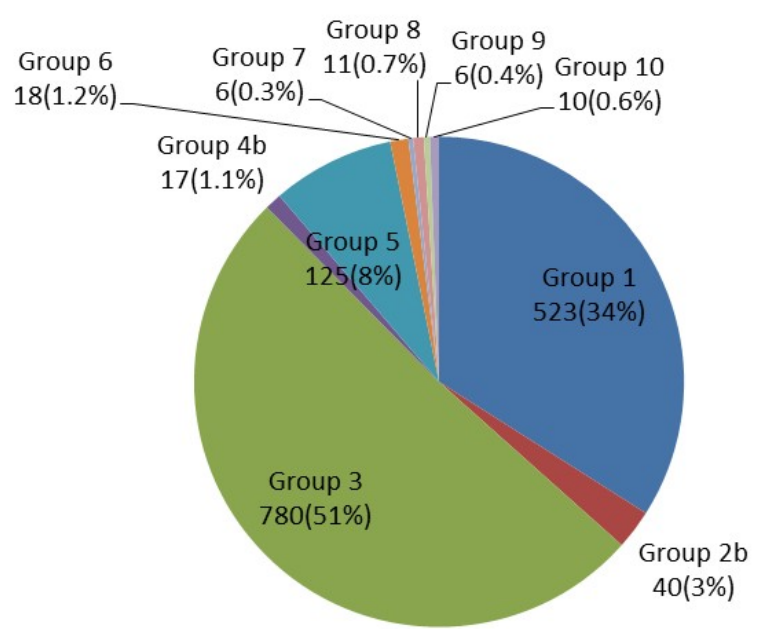

Figure-1: Robsons Group size of participants admitted for delivery $(\mathrm{N}=1536)$

Among the woman undergoing CS, half of participants $(50.5 \%)$ belonged to age group 20-24 years and majority $(38.1 \%)$ were from Dhanusa district. Majority participants were multiparous (61.47\%) with gestational age $>37$ weeks $(98.8 \%$ ) [Table-2].
Table-2: Demographic and Obstetric Profile of women undergoing caesarean section $(\mathrm{N}=257)$

\begin{tabular}{lll}
\hline \multicolumn{2}{c}{ Variables } & Number (\%) \\
\hline & $<19$ & $30(11.6 \%)$ \\
Age group in & $20-24$ & $130(50.5 \%)$ \\
years & $25-29$ & $80(31.1 \%)$ \\
& $30-34$ & $12(4.7 \%)$ \\
& $>35$ & $5(2 \%)$ \\
District address & Dhanusa & $98(38.1 \%)$ \\
by increasing & Mahottari & $86(33.4 \%)$ \\
distance & Sarlahi & $60(23.3 \%)$ \\
& Siraha & $8(3.1 \%)$ \\
Parity & Sindhuli & $5(2 \%)$ \\
& Nulliparous & $88(34.2 \%)$ \\
Period of gesta- & Multiparous & $158(61.4 \%)$ \\
tion & $<37$ weeks & $3(1.2 \%)$ \\
& $\geq 37$ weeks & $254(98.8 \%)$
\end{tabular}

According to Robsons classification, the overall caesarean section rate was $16.7 \%$ (257 among 1536). Group 5 (Previous CS) was the major contributor $(46 \%)$ to the overall CS rate followed by Group 2b (15.6\%) and Group 1(13.6\%) [Figure$2]$.

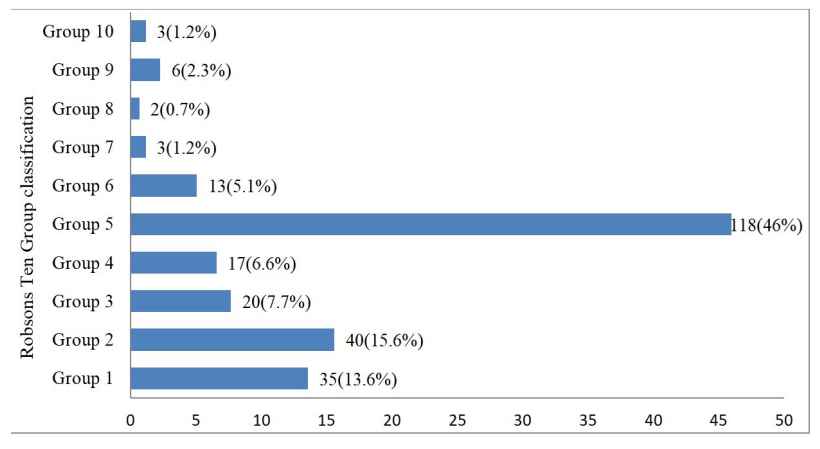

Figure-2: Robson Ten group Classification of women undergoing Caesarean section $(\mathrm{N}=257)$

Group CS rate was highest (100\%) for Group 2,4 and 9 while least (2.6\%) for Group 3 [Table-3].

\section{DISCUSSION}

This study included 1536 participants who delivered in Provincial hospital in 3 months. Lockdown due to COVID 19 pandemic might have affected the case load. Overall CS rate was $16.7 \%$ at this hospital during this period which is higher than that stated by WHO (10-15\%) and Karnali Academy of health sceinces (KAHS) $(9 \%){ }^{4,5}$ However, CS rate at this hospital is lower than Paropakar Maternity and Womens Hospital, a central referral hospital in kathmandu $(31.1 \%)^{8}$ and most of other public and private hospital in Nepal. ${ }^{4}$

In this study Robsons's Group 3 and 1 were the largest groups representing $85 \%$ of all obstetric population which is similar to the finding of Bar 
Table-3: Group CS rate and absolute group contribution to overall CS rate

\begin{tabular}{|c|c|c|c|c|}
\hline $\begin{array}{c}\text { Col- } \\
\text { umn } 1 \\
\end{array}$ & $\begin{array}{c}\text { Col- } \\
\text { umn } 2\end{array}$ & $\begin{array}{c}\text { Col- } \\
\text { umn } 3\end{array}$ & Column 5 & Column 6 \\
\hline Group & $\begin{array}{l}\text { Total } \\
\text { CS in } \\
\text { Group } \\
\text { (A) }\end{array}$ & $\begin{array}{c}\text { Total } \\
\text { Group } \\
\text { num- } \\
\text { ber } \\
\text { (B) }\end{array}$ & $\begin{array}{c}\text { Group CS } \\
\text { rate } \\
(\mathrm{A} / \\
\left.\mathrm{B}^{*} 100 \%\right)\end{array}$ & $\begin{array}{l}\text { Absolute } \\
\text { group con- } \\
\text { tribution to } \\
\text { overall CS } \\
\text { rate }(\mathrm{A} / \\
\left.\mathrm{Y}^{*} 100 \%\right)\end{array}$ \\
\hline 1 & 35 & 523 & 6.7 & 2.3 \\
\hline 2 & 40 & 40 & 100 & 2.6 \\
\hline $2 a$ & - & - & - & - \\
\hline $2 b$ & 40 & 40 & 100 & 2.6 \\
\hline 3 & 20 & 780 & 2.6 & 1.3 \\
\hline 4 & 17 & 17 & 100 & 1.1 \\
\hline $4 a$ & - & - & - & - \\
\hline $4 b$ & 17 & 17 & 100 & 1.1 \\
\hline 5 & 118 & 125 & 94.4 & 7.7 \\
\hline $5 a$ & 99 & 104 & 95.2 & 6.5 \\
\hline $5 b$ & 19 & 21 & 90.5 & 1.2 \\
\hline 6 & 13 & 18 & 72.2 & 0.8 \\
\hline 7 & 3 & 6 & 50 & 0.2 \\
\hline 8 & 2 & 11 & 18.2 & 0.1 \\
\hline 9 & 6 & 6 & 100 & 0.4 \\
\hline 10 & 3 & 10 & 30 & 0.2 \\
\hline Total & $257(\mathrm{X})$ & $1536(\mathrm{Y})$ & & 16.7 \\
\hline
\end{tabular}

caite et $\mathrm{al}^{9}$ where majority of participant were nulliparous or multiparous with single cephalic $\geq 37$ weeks admitted in spontaneous labor for delivery.

In this study Robson Group 5 (46\%), $2 \mathrm{~b}$ (15.6\%) and $1(13.6 \%)$ were the major contributor in overall $\mathrm{CS}$ rate. This finding is similar to the finding of Reddy AY et $\mathrm{al}^{10}$ where most CS (18.6\%) was done in Group 5 (Previous CS). Malla RV et $\mathrm{al}^{11}$ and Poudel $\mathrm{R}$ et $\mathrm{al}^{12}$ had different finding where majority of the CS belonged to Robsons Group 1 (nulliparous). This disparity could be the result of various factors like rising maternal age at first pregnancy, technological advances that have improved the safety of the procedure, changes in women's preferences, increasingly sedentary lifestyle and poor tolerance to pain. ${ }^{9,13}$ Even though, contribution to overall CS is different in various studies but Robson Group 5, 2 and 1 are major contributors at most of the centers.

Group CS rate for Robson's Group 9 (all abnormal lies including Previous CS) was $100 \%$ which seems very logical and is similar to other studies conducted by Reedy et $\mathrm{a}^{10}$ and Gomathy et $\mathrm{a}^{14}$ but as observed in this study Group CS rate for Robson Group 2 and 4 was also $100 \%$ which is unusual and is result of lack of induction facility at this hospital. None of the cases were admitted in Group 2a and $4 \mathrm{~b}$ for labor induction. Unavailability of labor induction has increased pre labor CS without giving trial for vaginal delivery. It has set background for further study and administrative analysis to make prop- er arrangements for labor induction and labor monitoring.

All these studies reflect the need to formulate strategies to reduce the incidence of medically unnecessary primary caesarean section ${ }^{15}$ which will decrease the rate of CS for previous CS in future. Similarly Dhakal et $\mathrm{al}^{3}$ has brought in the concept of Too Little Too Late (TLTL) referring to poor, lowly educated and vulnerable women who are in need have less or non- access to emergency obstetric care in rural areas due to limited provision of safe and timely CS procedure. Whereas,Too Much Too Soon (TMTS) refers to easily available private hospitals and education of women have been suggested as factors for rising of rates of CS in urban settings. Therefore, efforts should be made to provide caesarean sections to women in need, rather than striving to achieve a specific rate. ${ }^{16}$

\section{CONCLUSIONS}

Caesarean section at Provincial Hospital Janakpurdham is comparatively lower than other hospitals in Nepal. Arrangement of labor induction for Robson's Group 2a and 4a and promoting vaginal delivery in nullipara and facilitating VBAC are the most relevant areas of intervention. This study finding is limited by lack of induction of labor.

Financial disclosure: Received Provincial Health Research Grant 2020 from Nepal Health Research Council.

\section{REFERENCES}

1. Gary Cunningham F, Leveno Kenneth J, Bloom Steven L, Spong Catarine Y, Dashe Jodi S, Hoffman Barbara L, et al. Williams Obstertics $24^{\text {th }}$ Edition. New York: McGrraw Hill Education:2014.

2. Chhetri S, Singh U. Caesarean section: its rates and indications at a tertiary referral center in Eastern Nepal. Health Renaissance. 2011;9 (3):179-83. URL: https:// pdfs.semanticscholar.org/3951/0298768bf4b593 a8c10d9b9845f6fc2c9fe8.pdf

3. Rai SD, Regmi P, Van Teijlingen E, Wood J, Dangal G, Dhakal K. Rising Rate of Caesarean Section in Urban Nepal. J Nepal Health Res Counc. 2019;16(41):479-80. URL: https:// pubmed.ncbi.nlm.nih.gov/30739926/

4. Laxmi T, Goma D, Kumariniraula H, Roshnitui T, Binod A. Rising Cesarean Section Rates in Nepal: Question of safety and Integrity on Obstetric Emergency Practice. J Gynecol Women's Health. 2017;7(4):555716. URL: https:// juniperpublishers.com/jgwh/pdf/ JGWH.MS.ID.555716.pdf 
5. Betran AP, Torloni MR, Zhang J, Ye J, Mikolajczyk R, Deneux-Tharaux C, et al. What is the optimal rate of caesarean section at population level? A systematic review of ecologic studies. Reproductive Health. 2015;12(1):57. https:// www.ncbi.nlm.nih.gov/pmc/articles/ PMC4496821/

6. Robson MS. Classification of caesarean sections. Fetal and maternal medicine review. 2001;12 (1):23-39. https://sci-hub.tw/https:// doi.org/10.1017/S0965539501000122

7. Kanta A, Mediratta S. Classification of cesarean section through Robson criteria: an emerging concept to audit the increasing cesarean section rate. Int J Reprod Contracept Obstet Gynaecol. 2018;7(11):4674-77. https://sci-hub.tw/http:// dx.doi.org/10.18203/2320-1770.ijrcog20184528

8. Shrestha M, Shrestha S. Cesarean Section profile at a tertiary center. Nepal Journal of Obstetrics and Gynaecology. 2020 Jun 7;15(1):68-71. https://www.nepjol.info/index.php/NJOG/article/ view/29345

9. Barčaitė E, Kemeklienė G, Railaitè DR, Bartusevičius A, Maleckienė L, Nadišauskienė R. Cesarean section rates in Lithuania using Robson ten group classification system. Medicina. $2015 ; 51$ (5):280-5. https://sci-ub.tw/https:// doi.org/10.1016/j.medici.2015.09.001

10.Reddy AY, Dalal A, Khursheed R. Robson ten group classification system for analysis of cesarean sections in an Indian hospital. Res J Obstet Gynecol. 2018;11:1-8. https://scialert.net/ abstract/?doi=rjog.2018.1.8
11.Malla RV, Hamal C, Neupane B, Khatri R. Analysis of Cesarean Section Using Robson's 10-Group Classification at a Tertiary Level Hospital in Nepal. Med J Shree Birendra Hosp. 2018;17(2):4-11. https://sci-hub.tw/https:// doi.org/10.3126/mjsbh.v17i2.20290

12.Poudel R, Dangal G, Karki A, Pradhan HK, Shrestha R, Bhattachan K, et al. Assessment of Caesarean Section Rates at Kathmandu Model Hospital Using the Robson's Ten Group Classification System. J Nepal Health Res Counc. 2019;17(4):491-4. PMID: 32001854

13.Bragg F, Cromwell DA, Edozien LC, GurolUrganci I, Mahmood TA, Templeton A, et al. Variation in rates of caesarean section among English NHS trusts after accounting for maternal and clinical risk: cross sectional study. BMJ. 2010;341:c5065. URL: https://scihub.tw/10.1136/bmj.c5065

14.Gomathy E, Radhika K, Kondareddy T. Use of the Robson Classification to assess caesarean section trends in tertiary hospital. Int J Reprod Contracept Obstet Gynecol. 2018;7(5):17961800. URL: https://www.ijrcog.org/index.php/ ijrcog/article/view/4541

15. Vogel JP, Betrán AP, Vindevoghel N, Souza JP, Torloni MR, Zhang J, et al. Use of the Robson classification to assess caesarean section trends in 21 countries: a secondary analysis of two WHO multicountry surveys. The Lancet Global Health. 2015;3(5):e260-70.URL: https://sci-hub.tw/10.1016/S2214-109X(15) 70094-X

16. World Health Organization. Statement on caesarean section rates. URL: https:// apps.who.int/ iris/bitstream/handle/10665/161442/ 